\title{
Sejarah Nalar Diplomasi Politik Indonesia di Kawasan Timur Tengah
}

\author{
Imam Nawawi \\ Mahasiswa Pascasarjana Kajian Timur Tengah (KTT) UIN Sunan Kalijaga Yogyakarta \\ felem2imam@gmail.com
}

\begin{abstract}
:
The historiography of Indonesian political diplomacy in the Middle-East regions faces obstacles from the researchers themselves. The perspective contradictions are compounded by sorting data and sources. The appearance of Indonesian political diplomacy in the Middle East regions according to the Middle East researchers and academics themselves seems to be gloomy and lethargic, because they demand more than what Indonesia has achieved and done. Indonesia is considered not too interested in contributing to the recovery of conflict countries and the acceleration of the transition to democratic values. According to the other researchers who are not based on the Middle East institutions, the appearance of Indonesian political diplomacy in the Middle East is quite positive and slightly vague. Unlike the case with the version that came out directly from the Government of the Republic of Indonesia about their achievements and performance in building diplomatic relations with related countries in the Middle East. Some achievements are recorded annually and submitted to the public in their annual reports. The constraints in historical writing can be overcome by the historical reasoning approach which tries to examine reason, thought and awareness, and which not only focuses on historical facts and events themselves. This approach is able to map the narrative contestation and discourse ideology, and find solutions to the problems.
\end{abstract}

Keywords: History, Historiography, Middle East, Political Diplomacy, Reason and Narrative.

\begin{abstract}
Abstraksi
Penulisan sejarah diplomasi politik Indonesia di kawasan Timur Tengah tersandera oleh kepentingan peneliti sendiri. Kontradiksi perspektif diperparah dengan penyortiran data dan sumber. Wajah diplomasi politik Indonesia di Kawasa Timur Tengah menurut kacamata peneliti dan akademisi Timur Tengah sendiri tampak suram dan lesu, karena mereka menuntut hal yang lebih dari yang telah dicapai dan dikerjakan oleh Indonesia. Indonesia dinilai tidak terlalu berminat dalam berkontribusi mendorong pemulihan negara-negara berkonflik dan percepatan transisi ke nilai-nilai demokratik. Di mata peneliti lain, yang secara institusi tidak berbasis Timur Tengah, wajah diplomasi politik Indonesia di Timur Tengah lumayan positif dan sedikit samar-samar. Berbeda halnya
\end{abstract}


Millatī, Journal of Islamic Studies and Humanities, Vol. 3, No. 1, Juni 2018: 73-101

dengan versi yang keluar langsung dari Pemerintah Republik Indonesia tentang prestasi dan kinerja mereka dalam membangun hubungan diplomatik dengan negara-negara sahabatnya di Timur Tengah. Pencapaian demi pencapaian tercatat setiap tahun dan disampaikan ke publik dalam laporan tahunan mereka. Kendala-kendala dalam penulisan sejarah ini dapat diatasi dengan pendekatan historical reasoning, yang mencoba mengkaji nalar, pemikiran dan kesadaran, yang tidak saja terfokus pada fakta dan peristiwa sejarah itu sendiri. Pendekatan ini mampu memetakan kontestasi narasi dan ideologi wacana, serta membuka pintu keluar dari problematiknya.

Kata kunci:Sejarah, Historiografi, Timur Tengah, Diplomasi Politik, Nalar dan Narasi.

\section{Pendahuluan}

Para ilmuan barat telah banyak meninggalkan cara belajar sejarah yang hanya berfokus pada peristiwa (events) dan fakta masa lalu (facts of the past). Lebih dari itu, mereka mempelajari nalar, kesadaran atau pemikiran yang historis. Jannet van Drie dan Carla van Boxtel (2007) membuat daftar nama-nama ilmuan yang telah berhasil mengembangkan cara-cara baru dalam melakukan pembacaan kritis terhadap sejarah. Di antara nama mereka dan cara baru (terms) yang dikembangkan adalah Lee (2004), Perfetti (1995) dan Roderigo (1994) dengan historical literacy; Seixas (1993), Husbands (1996), Van Sledright dan Frankes (2000), Wineburg (2001) dan Schreiber (2006) yang mengembangkan historical thinking; Jeismann (1997), Von Borries (1997) dan Goegebeur (1999) yang mengembangkan historical consciousness; dan Kuhn (1994) dan Leinhardt (1994) yang mengembangkan historical reasoning. ${ }^{1}$

Pemikiran, kesadaran dan nalar bukan peristiwa dan fakta eksternal melainkan dimensi abstraksi yang internal dalam diri manusia. Dimensi internal yang abstrak ini berkedudukan sama dengan peristiwa dan fakta sejarah namun berbeda soal dimensinya. Menjadikan pemikiran, kesadaran dan nalar sebagai objek material kajian sejarah melahirkan narasi tentang sejarah pemikiran, kesadaran dan nalar itu sendiri. "Sejarah Nalar" atau "Sejarah Kesadaran" dalam konteks interpretasi tulisan ini merujuk pada suatu framework pembacaan sejarah yang tidak saja membatasi diri pada fakta dan peristiwa masa lalu melainkan juga pada nalar (reason), kesadaran (consciousness) dan cara berpikir (thinking) yang

${ }^{1}$ Jannet van Drie dan Carla van Boxtel, "Historical Reasoning: Towards a Framework for Analyzing Students' Reasoning about the Past,” dalam Educ Psychol Rev, Springer, No. 20, Thn 2008, h. 88 
berjalin kelindan dalam fakta dan peristiwa sejarah tersebut.

Diplomasi seperti yang didefinisikan R.P. Barston (2014) merupakan aktifitas mengatur, mengelola dan manajerial relasi-relasi antar dua negara atau antara negara dan aktor-aktor lain. ${ }^{2}$ Sebagai peristiwa yang tidak terlepas dari ruang, waktu dan aktor-aktornya, diplomasi politiksecara inheren lahir dari sebuah nalar, kesadaran dan pemikiran. Dapat dikatakan pula, nalar diplomasi politikmenjadi objek material yang bisa dianalisis di level akademik. Nalar diplomasi politik Indonesia di negara-negara kawasan Timur Tengah merupakan fokus kajian tulisan ini.

Sejarah nalar diplomasi politikIndonesia di kawasan Timur Tengah, dengan begitu, merupakan suatu pembacaan historis atas nalar kesadaran diplomatik Indonesia di kawasan Timur Tengah dalam bidangpolitik. Suguhan terpenting dalam tulisan ini adalahreason, thinking, dan counsciousness yang berpijak pada fakta dan peristiwa diplomasi di bidang politik. Bagaimana nalar dan kesadaran itu terbentuk, bagaimana relasinya dengan narasi-narasi yang berkontestasi untuk merebut panggung, serta bagaimana mempertemukan konstruk naratif yang mencerminkan nalar diplomatik Indonesia di negara kawsan Timur Tengah merupakan tema utama dalam tulisan ini.

Riset akademik yang berfokus pada sejarah nalar diplomasi Indonesia di kawasan Timur Tengah tidak banyak dilakukan. Sekalipun ada, riset-riset yang berkembang selama ini terjebak oleh "framework konvensional" dalam memotret peristiwa sejarah, baik yang classical history maupun recent history. Dalam artian, penulisan sejarah diplomasi Indonesia di Timur Tengah berkutat pada persoalan peristiwa dan fakta, belum melompat ke dimensi nalar, kesadaran dan cara berpikir yang tercermin pada produk diplomatisnya.

Muhammad Tri Andika (2016) mengangkat "An Analysis of Foreign Policy Under Jokowi's Pro-People Diplomacy”. Di sini, Tri Andika membahas panjang lebar peristiwa dan fakta sejarah yang terjadi di era Presiden Joko Widodo, dan sesekali membandingkannya dengan peristiwa dan fakta sejarah yang pernah terjadi di era Presiden Susilo Bambang Yudhoyono sebagai pendahulunya.

Dalam risetnya, Muhammad Tri Andika berhasil menggambarkan jargon "Turun ke Bawah (down to earth diplomacy)" atau "Diplomasi Pro-Rakyat (pro-people diplomacy)" yang dikembangkan oleh Presiden Joko Widodo. Tidak saja itu, Tri Andika mengkomparasikannya denganjargon "Nol Musuh, Seribu

\footnotetext{
${ }^{2}$ R.P. Barston, Modern Diplomacy, (New York: Routledge, 2014), h. 1.
} 
Millatī, Journal of Islamic Studies and Humanities, Vol. 3, No. 1, Juni 2018: 73-101

Teman (Zero Enemy and Thousands Friends)" yang dikembangkan oleh Presiden Susilo Bambang Yudhoyono. ${ }^{3}$

Dalam kacamata teoritik dari Jannet van Drie dan Carla van Boxtel, analisa Muhammad Tri Andika telah memenuhi beberapa komponen dasar historical reason. M. Tri Andika menyugukan sumber-sumber data, argumentasi, kontekstualisasi, sampai melahirkan satu rumusan konseptual. Tri Andika sampai pada kesimpulan bahwa down to earth diplomacy dari Jokowi adalah tandingan bagi pola diplomasi Zero Enemy and Thousands Friends. Jokowi lebih membumi,sedangkan SBY terlalu elit dan melangit. ${ }^{4} \mathrm{M}$. Tri Andika juga sampai pada kesimpulan bahwa style diplomasi ala SBY dievaluasi dengan style diplomasi Jokowi, yang menjadikan kepentingan domestik sebagai standard mengembangkan kebijakan di level internasional, serta memberi catatan bahwa style baru Jokowi tersebut harus dijelaskan dengan lebih baik ke negara-negara tetangga terutama ASEAN agar tidak menimbulkan kekhawatiran yang akan menilai Indonesia abai pada isu-isu internasional.

Penjelasan yang apik dari riset M. Tri Andika di atas menyisakan ruang masalah, yaitu soal meta konsep yang tidak terbangun. Pemenuhan meta konsep ini penting dalam sebuah kerja riset sebab akan mengantarkan pada sejauh mana kesimpulan-kesimpulan setiap sub bahasannya terbuka untuk diukur menggunakan fakta-fakta lain yang tidak terangkum dalam temuannya. Faktafakta lain ini sangat mungkin dilakukan oleh para peneliti dalam penelitianpenelitian mereka berikutnya. Tanpa meta konsep menyebabkan konsep yang dirumuskan terikat pada sumber-sumber sejarah dan sekaligus mencerminkan kerja konvensional dari historiografi. Dalam artian, cara kerja Muhammad Tri Andika adalah cara kerja sejarawan klasik yang masih terjebak pada sebatas fakta dan peristiwa.

Riset lainnya dilakukan oleh Aaron L. Connely (2014) yang juga bicara kebijakan diplomatik era Presiden Jokowi dan membandingkannya dengan era Presiden Susilo Bambang Yudhoyono. Dalam analisanya, A. L. Connely menilai Presiden Jokowi tidak berpengalaman dalam urusan diplomasi luar negeri. Sebagai konsekuensinya, presiden harus menyerahkan urusan diplomasi ke para "penasehatnya (advisers)" yang dinilai jauh lebih berpengalaman, sangat

${ }^{3}$ Muhammad Tri Andika, "An Analysis of Indonesia Foreign Policy Under Jokowi's Pro-People Diplomacy," dalam Indonesian Perspective, Vol. 1, No. 2 (2016), h. 1-13

${ }^{4}$ Ibid., h. 10 
internasionalis, dan elite dalam berdiplomasi di level internasional. ${ }^{5}$

Aaron L. Connely sampai pada kesimpulan bahwa apabila Jokowi berhasil mengatasi serangan para oposisi di tingkat domestik maka dia akan memberikan kontribusi besar pada pembangunan dan demokrasi Indonesia. Tetapi, tidak adanya pengalaman yang baik untuk urusan diplomasi luar negeri dan fokusnya pada reformasi kebutuhan dalam negerimembuat pemerintahannya akan bersifat reaksioner nasionalistik dalam merespon isu-isu internasional. ${ }^{6}$

Di titik ini, hasil analisa dan riset Aaron L. Connely sejalan dengan M. Tri Andika, yang mengkhawatirkan style diplomasi politik rezim Jokowi di kancah internasional namun positif bagi upaya pemenuhan kepentingan domestik. Sedangkan style diplomasi rezim SBY positif di level internasional dan belum maksimal untuk kepentingan domestik. Perbedaannya, jika M. Tri Andika memberikan saran bahwa yang harus dilakukan Indonesia era Jokowi adalah menjelaskan style diplomasinya ke negara-negara partner seperti ASEAN, Aaron L. Connely mewanti-wanti negara Australia agar lebih hati-hati menjalin kerjasama dengan Indonesia.

Dalam kacamata teoritik Jannet van Drie dan Carla van Boxtel, riset Aaron L. Connely tidak jauh berbeda dari Muhammad Tri Andika, yaitu menghadirkan data-data sejarah sebagaimana ditemukan dalam sumber-sumber, kemudian mengajukan argumentasi, melakukan kontekstualisasi, dan berakhir dengan menyusun sebuah konsep yang substantif. Celah yang terjadi dalam hasil riset M. Tri Andika juga terjadi dalam hasil riset A. L. Connely, yaitu absennya meta konsep. Sehingga, keduanya tidak membuka diri pada kemungkinan riset berikutnya, yang tidak menutup kemungkinan menaruh perspektif berbeda dan bahkan mungkin bertolak belakang sekalipun mengangkat isu yang sama, yaitu diplomasi politik Indonesia.

${ }^{5}$ Aaron L. Connely, Indonesian Foreign Policy Under President Jokowi, (Australia: Lowy Institute, 2014), h. 1-15. Perlu diketahui bahwa Aaron L. Connely adalah seorang peneliti yang bekerja di lembaga The Lowy Institute for International Policy. Lembaga ini think tank independen yang mengkaji kebijakan-kebijakan pemerintah. Tanggungjawab yang ingin diperjuangkan oleh lembaga ini adalah seluruh dimensi perdebatan kebijakan internasional Australia, termasuk ekonomi, politik dan strategi. Lembaga ini tidak menentukan wilayah tertentu, karenanya dia punya dua inti tanggungjawab: a) memproduksi riset berbeda dan opsi kebijakan yang fresh bagi kebijakan internasional Australia, serta berkontribusi pada perdebatan akademik internasional yang lebih luas, b) mempromosikan diskusi seputar peran Australia di dunia dengan menyediakan forum diskusi tentang Australia yang lebih terakses melalui debat, seminar, kuliah, dialog, dan konferensi.

$$
{ }^{6} \text { Ibid., h. } 15
$$


Terbukti adalah hasil riset dari Büllet Aras dan Sinan Ekim. Mengingat Muhammad Tri Andika dan Aaron L. Connely sama-sama tidak membahas masalah diplomasi Indonesia dengan negara-negara kawasan Timur Tengah, riset yang dilakukan Büllet Aras dan Sinan Ekim (2015) datang melengkapi. Büllet Aras dan Sinan Ekim mengangkat tema Indonesia and the Arab Spring.

Büllet Aras dan Sinan Ekim juga berbicara kebijakan diplomatik Indonesia di era Joko Widodo dan Susilo Bambang Yodhoyono. Perbedaannya dibanding Connely dan Andika, Büllet Aras dan Sinan Ekim mengembangkan isu politik bebas aktif Indonesia dan peran kontributifnya bagi persoalan fundamentalisme agama dan kemunculan gerakan Iraq and Syria Islamic State (ISIS) di Timur Tengah. Secara umum dapat digambarkan bahwa komitmen Indonesia baik era SBY maupun Jokowi terhadap upaya penyelesaian konflik kawasan Timur Tengah sangat rendah. Hal itu tercermin dari kebijakan-kebijakannya yang terlalu lembut, soft, dan sering kali abstain. Di beberapa kasus seperti Suriah, Libya, Kairo dan Tunisia, kehadiran Indonesia tidak terasa. ${ }^{8}$

Büllet Aras dan Sinan Ekim juga membidik prospek bekerjasama dengan Indonesia bagi negara-negara Timur Tengah di bidang ekonomi. Sekalipun, mereka menyiratkan aura pesimisme, suatu perasaan pesimis yang juga tergambar dalam peran kontributif Indonesia di ranah politik diplomatik. Kesan pesimis itu muncul karena melihat agresifitas Indonesia di Timur Tengah dalam bidang ekonomi terlihat kurang semangat. Menurut mereka, partner utama Indonesia adalah Cina, Jepang, Singapura, Uni Eropa, Amerika, Malaysia, India, Korea,

${ }^{7}$ Büllet Aras dan Sinan Ekim, "Indonesia and Arab Spring," dalam POMEAS POLICY PAPER, Istanbul, No. 6, Mei 2015, 1-9. Perlu diketahui bahwa Bullet Aras adalah seorang kordinator akemik dalam Project on the Middle East and the Arab Spring (POMEAS), sekaligus seorang profesor di bidang Hubungan Internasional di Sabancı University. Jabatan lain Bullet Aras adalah ketua Center for Strategic Research (SAM), the Diplomatic Academy at Turkish, Ministry of Foreign Affairs antara tahun 2010 hingga 2013. Selain itu, dia juga profesor tamu di TurkishStudiesdi St. Anthony's College, University of Oxford tahun 2010. Sinan Ekim Assisten Peneliti di Istanbul Policy Centre. Dia juga lulusan London School of Economics and Political Science, dan sebelumnya menempuh studi di Istituto Affari Internazionali, Roma.

Project on the Middle East and the Arab Spring (POMEAS) bertujuan merespon pergolakan politik timur tengah yang bermula sejak tahun 2011 di Timur Tengah, Afrika Utara, dan perkembangan-perkembangan berikutnya. POMEAS juga punya keyakinan bahwa proses-proses penelitian akademik, debat dan disukusi publik dapat berkontribusi pada masyarakat Timur Tengah. POMEAS ingin memberikan dampak baik pada diskusi kalangan pakar maupun atmosfer opini publik. POMEAS beralamat di Bankalar Caddesi, No: 2 Sabancı University Karaköy Minerva Han 34420 Karakoy / Istanbul - TURKEY.

${ }^{8}$ Ibid., h. 2-5 
Thailan dan Australia. Pesimisme juga dikarena Indonesia tidak terlihat agresif untuk menyeimbangkan konflik Sunni-Syiah, Saudi-Iran, yang menjadi motor utama problem di Timur Tengah. ${ }^{9}$

Büllet Aras dan Sinan Ekim melakukan kegagalan yang sama seperti dilakukan Aaron L. Connely dan Tri Andika. Pembaca yang kritis mengerti apa yang menjadi harapan para peneliti asing itu, dan kerja-kerja riset semacam apa yang perlu ditindaklanjuti.Kegagalan Büllet Aras dan Sinan Ekim tercermin pada cara mereka memahami peran dan posisi diplomatik Indonesia di level internasional. Mereka berpikir, Indonesia baik di bawah Yudhoyono maupun Jokowi "did not find any value in deploying troops to topple down dictators, or dispatching political experts to ensre a successful transtition." pasukan militer untuk menggulingkan diktator atau mengirim pakar politik untuk mensukseskan transisi menuju sistem yang lebih demokratik.

Pembacaan yang utuh atas peristiwa dan fakta sejarah selalu tidak akan terhenti pada pembentukan konsep yang final melainkan juga membuka diri untuk membicarakan dan dibicarakan dimensi berikutnya, yaitu meta konsepnya. Karena alasan itulah, framework sejarah nalar yang dikembangkan oleh Jannet dan Calra (2008) ini memiliki 6 (enam) komponen utama: 1) menanyakan pertanyaan-pertanyaan historis, 2) menggunakan berbagai sumber, 3) kontekstualisasi, 4) argumentasi, 5) menggunakan konsep-konsep substantif, dan 6) menggunakan meta konsep.

Bagi Jannet dan Carla, seorang pelajar maupun peneliti sejarah perlu mengajukan pertanyaan-pertanyaan yang historis yang digali dari berbagai sumber untuk menemukan urgensi kekiniannya atau kontekstualisasinya. Dalam melakukan tanya-jawab dan diskusi seputar sejarah itu akan muncul konsepkonsep substantif yang dapat menggambarkan peristiwa sejarah. Konsep yang terbentuk ini bisa menjadi bahan lompatan perenungan berikutnya, dan dari sanalah meta konsep baru mulai terilustrasi. ${ }^{11}$

Enam komponen historical reasoning ini berjalin kelindan, saling terhubung. Dengan sendirinya, hasil analisa akan bersifat komprehensif, terbuka, dinamis dan progresif. Tidak ada keterputusan antara data dengan analisa, antara analisa dengan konsep yang terbentuk, antara konsep dengan kritik atas konsep,

\footnotetext{
${ }^{9}$ Ibid., h. 6-7

${ }^{10}$ Ibid., h.

${ }^{11}$ Jannet van Drie dan Carla van Boxtel, "Historical Reasoning: Towards a Framework for Analyzing Students' Reasoning about the Past," ibid., 89
} 
Millatī, Journal of Islamic Studies and Humanities, Vol. 3, No. 1, Juni 2018: 73-101

dan seterusnya. Sebuah teks dipaksa untuk dimaknai secara kontekstual, atau sebaliknya, konteks dapat ditarik masuk ke dalam teks. Peristiwa diplomatik Indonesia di Timur Tengah secara khusus maupun Indonesia dengan negaranegara partner harus dibacara terus-menerus.

Untuk memudahkan pemahaman tentang kerangka kerja analitik dari teori historical reasoningversi Jannet dan Carla, perhatikanlah skema/bagan berikut ini: ${ }^{12}$

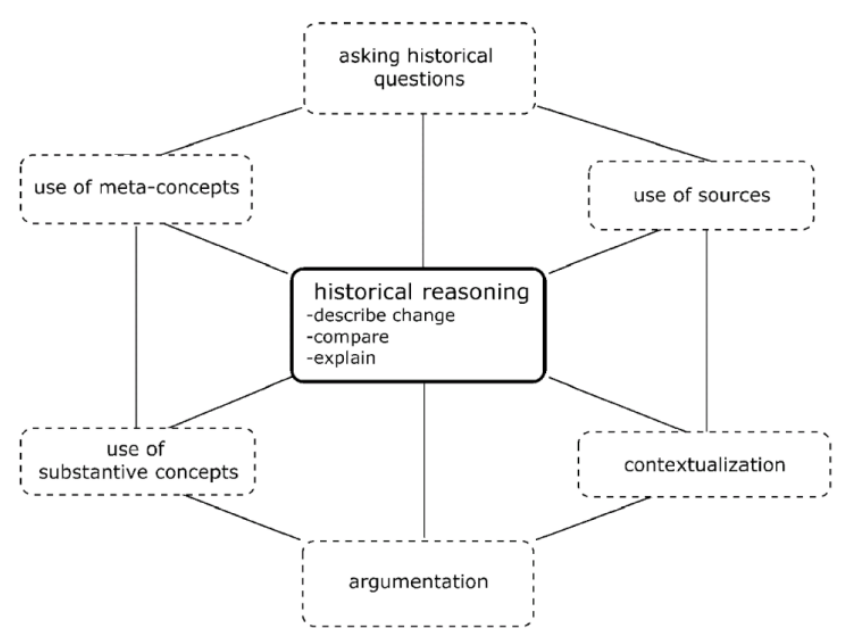

\section{Gambar: 6 Komponen Historical Reasoning}

Melalui tulisan ini, penulis ingin memberikan gambaran yang proporsional tentang nalar diplomatik Indonesia di kawasan Timur Tengah dengan pembacaan yang lebih komprehensif. Dengan pendekatan sejarah, bidang politik akan menjadi sampel kajian. Teori historical reason dari Jannet van Drie dan Carla van Boxtel akan membantu mengarahkan analisa sehingga lebih tajam dan berbobot.

Dalam bidang politik, Indonesia dan negara-negara kawasan Timur Tengah memiliki sejarah diplomasi yang panjang, dengan pencapaian yang terus membaik, sekalipun bergelombang dan pasang surut sesuai situasi temporal. Semua ini merupakan sumber sejarah diplomasi Indonesia dan Timur Tengah yang berguna bagi perenungan filosofis untuk mengkonstruksi bangunan nalar, kesadaran dan cara berpikir Indonesia dalam berdiplomasi dengan negara-negara Timur Tengah.

${ }^{12}$ Ibid., h. 90 
Konstruksi awal ini akan selalu terbuka untuk dikaji secara kritis demi menemukan pola konstruksi yang lebih utuh. Dengan begitu, pembaca sejarah yang kritis tidak terjebak oleh konstruksi nalar yang given,yang melekat secara inheren dan yang tersembunyi di dalam sumber-sumber sejarah yang menjadi rujukannya.

\section{Konteks Makro Diplomasi Indonesia Sejak SBY hingga Jokowi}

Hal paling mendasar dalam wacana historical reasoning adalah soal historical questions. Dari pertanyaan historis inilah akan tergambar upaya strategis pembacaan sejarah untuk memperoleh domain spesifik. Dengan mengutip Schreiber (2006), Jannet dan Carla memaparkan tentang willingness and ability to ask, recognize and understand historical questions as one of the competencies underlying historical thinking. ${ }^{13}$ Dalam penelitian ini, penting diajukan pertanyaan historis tentang bagaimana gambaran makro diplomasi era Presiden Susilo Bambang Yudhoyono hinga Joko Widodo dengan harapan jawabannya menjadi objek material perenungan filosofis.

Kita tahu bahwa setelah Presiden Megawati lengser, Susilo Bambang Yudhoyono (SBY) maju sebagai penggantinya pada tahun 2004. Nalar diplomasi Indonesia hendak untuk menyelesaikan berbagai permasalahan domestik akibat krisis 1997. SBY melakukan revitalisasi peran internasional Indonesia agar dapat kembali berperan aktif dan berkontribusi terhadap permasalahan internasional, termasuk pemenuhan kepentingan nasional melalui instrumen politik luar negeri.

Peringatan ke-50 Konferensi Asia-Afrika pada April 2005 menawarkan kerja sama New Asian-African Strategic Partnership (NAASP).Kesan pemerintahan SBY berkeinginan kuat untuk kembali aktif dalam pergaulan masyarakat internasional muncul. SBY berusaha merangkul sebanyak mungkin pihak dalam kerangka kemitraan yang saling menguntungkan dan memberikan penekanan pada konektifitas melalui proses diplomasi.

Zero enemy thousands friends adalah jargon Presiden SBY dalam membangun kedekatan hubungan dengan negara-negara mitra kunci, baik negara maju maupun berkembang, dalam bentuk strategic partnerships ataupun comprehensive partneship. Kemitraan strategis maupun kemitraan komprehensif merupakan

${ }^{13}$ Jannet van Drie dan Carla van Boxtel, "Historical Reasoning: Towards a Framework for Analyzing Students' Reasonin g about the Past,” ibid., h. 90-1 
Millatī, Journal of Islamic Studies and Humanities, Vol. 3, No. 1, Juni 2018: 73-101

suatu upaya untuk menyusun struktur hubungan, persetujuan berdasarkan prioritas dan bagaimana untuk mencapai target yang telah ditetapkan sehingga hubungan kemitraan yang telah terjalin menjadi lebih terukur dan dapat diprediksi. ${ }^{14}$

Kemitraan strategis maupun komprehensif ini menjadi bagian penting diplomasi luar negeri Indonesia yang lebih pro-aktif dan well thought out, dimana Indonesia ingin dilihat sebagai negara yang secara strategis dan politis mempunyai arti bagi stabilitas dan perdamaian kawasan.

\section{Tiongkok}

Persetujuan Kemitraan Strategis (Strategic Partnership Agreement) antara Indonesia dengan Tiongkok ditandatangani pada 25 April 2005. Terdapat tiga bidang luas yang dicakup dalam perjanjian kemitraan strategis ini, yaitu kerjasama politik dan keamanan, kerjasama ekonomi dan pembangunan, dan kerjasama sosial budaya.

Kemitraan strategis Indonesia dengan Tiongkok terselenggara utamanya karena dilatarbelakangi oleh kesamaan kepentingan kedua negara. Dalam pandangan Indonesia, Tiongkok adalah salah satu kekuatan regional dan sekaligus kekuatan global yang pengaruhnya semakin meningkat. Kedudukan dan peran Tiongkok yang menonjol tersebut diharapkan dapat memberikan kontribusi dalam hubungan dan kerjasama kawasan. Sebaliknya, Tiongkok memandang Indonesia sebagai mitra strategis yang memiliki peran penting bagi stabilitas kawasan dan memiliki potensi ekonomi yang cukup besar, sekaligus juga tetangga yang bersahabat (friendly neighbors). ${ }^{15}$

\section{Jepang}

Kemitraan strategis Indonesia dengan Jepang secara resmi ditandatangani oleh Presiden SBY dan Perdana Menteri Shinzo Abe pada 28 November 2006. Jepang merupakan mitra dagang terbesar Indonesia. Indonesia menjadi salah satu negara pemasok utama kebutuhan energi Jepang untuk keperluan industri seperti gas alam, batu bara, nikel; sementara Jepang menjadi negara donor utama sekaligus salah satu negara investor terbesar dalam penanaman modal asing di Indonesia. Pada 20 Agustus 2007, Indonesia dan Jepang menandatangani kesepakatan pembentukan Indonesia and Japan Economic Partnership Agreement

${ }^{14}$ Triyono Wibowo, "Hubungan Strategis ASEAN-China, Pilar bagi Arsitektur Kerjasama Regional”, dalam Tabloid Diplomasi, No. 19, Tahun ke-II,. 15 Juni - 14 Juli, 2009, h. 16

${ }^{15}$ Ibid., h. 16 
(IJEPA) sebagai salah satu sarana untuk meningkatkan volume perdagangan kedua negara sekaligus memfasilitasi investasi Jepang di Indonesia.

\section{India}

Kemitraan strategis Indonesia dengan India telah ditandatangani secara resmi pada November 2005, ketika Presiden SBY melakukan kunjungan kenegaraan ke India. Pada kunjungan kenegaraan Presiden SBY ke India ditahun 2011, kedua negara kembali menyepakati untuk memperkuat kemitraan strategis yang telah terjalin sebagai bentuk langkah konkret untuk mencapai kemajuan dan kesejahteraan yang berkelanjutan bagi kedua negara. Dalam joint statement-nya, Presiden SBY dan PM Manmohan Singh menyatakan keinginan mereka untuk memainkan peran aktif untuk mempromosikam demokrasi, perdamaian dan stabilitas di kawasan Asia Pasifik dan dunia.

\section{Amerika Serikat}

Kemitraan komprehensif Indonesia-AS ditandatangani secara resmi pada November 2010 ketika Presiden Obama melakukan kunjungan kenegaraan ke Indonesia. Terdapat tiga bidang kerjasama yang tercakup dalam kemitraan komprehensif Indonesia-AS ini, yaitu bidang politik dan keamanan, ekonomi dan pembangunan, sosial-budaya, pendidikan, ilmu pengetahuan dan teknologi. Secara politis, kemitraan komprehensif ini dapat membantu penguatan kapasitas institusi-institusi demokrasi di Indonesia.

Dari perspektif ekonomi, kemitraan komprehensif ini dapat meningkatkan aktifitas ekonomi kedua negara seperti perdagangan dan investasi sekaligus dukungan dan bantuan untuk menguatkan fondasi ekonomi Indonesia khususnya dalam hal pendidikan, kesehatan, infrastruktur, manufaktur dan teknologi. Kemitraan ini juga dapat meningkatkan peran Indonesia sebagai mitra Amerika Serikat dalam mengatasi berbagai isu global. ${ }^{16}$

Ketika kekuasaan SBY berakhir dan berpindah ke tangan Presiden Joko Widodo, Indonesia selalu menekankan pentingnya akan diplomasi ekonomi Indonesia. Pada masa kepemimpinannya ini nampak jelas bahwa salah satu prioritas politik luar negeri Indonesia adalah diplomasi ekonomi. Dalam misi diplomasi ekonomi ini, presiden yang akrab dipanggil Jokowi itu menargetkan surplus perdagangan, menggenjot upaya-upaya dalam memasarkan potensi

${ }^{16}$ Rizal Sukma, “An Indonesian Vision,” dalam Abraham M. Denmark, Crafting A Strategic Vision: A New Era of USIndonesia Relations, (New York: Center for New American Security, 2010), h. 14 
Millatī, Journal of Islamic Studies and Humanities, Vol. 3, No. 1, Juni 2018: 73-101

ndonesia serta mendukung usaha-usaha kecil menengah Indonesia agar dapat menembus pasar internasional. Untuk itu, para diplomat Indonesia dituntut untuk menjadi 'salesperson' di luar negeri.

Salah satu aspek penting dari diplomasi ekonomi adalah meningkatkan kerjasama perdagangan, investasi, dan pariwisata (Trade, Tourism, Investment/TTI). Adapun salah satu tujuan utama kerjasama TTI tersebut adalah mendorong ekspor Indonesia, meningkatkan investasi dan meningkatkan kunjungan wisatawan mancanegara, dalam rangka mendorong perekonomian nasional. Guna mendukung upaya tersebut, Kemlu maupun Kementerian/Lembaga lainnya secara proaktif menyelenggarakan promosi Trade, Tourism, and Investment (TTI) keluar negeri. Terdapat indikasi bahwa TTI yang telah diselenggarakan selama ini masih belum optimal, berjalan sendiri-sendiri sehingga hasil/manfaat yang dicapai tidak maksimal. ${ }^{17}$

Tren saat ini menggambarkan kerjasama hubungan perdagangan SelatanSelatan semakin meningkat, khususnya sejak krisis ekonomi di AS dan Eropa Barat mulai tahun 2008. Dalam kaitan ini, Indonesia termasuk salah satu negara yang mencoba melakukan upaya untuk meningkatkan perdagangannya di pasar non-tradisional. Namun demikian, upaya tersebut masih belum membuahkan hasil yang optimal. Hal ini tercermin, misalnya, pada data perdagangan Indonesia dengan negara-negara pasar non-tradisional seperti Afrika yang besarnya masih dibawah beberapa negara Asia lainnya, seperti Tiongkok, India dan Thailand. ${ }^{18}$

Sesuai rencana program era Pemerintahan Baru 2014-2019, Kemlu dituntut untuk memperkuat kinerja diplomasi ekonomi dan salah satu dari rincian program diplomasi ekonomi adalah mengefektifkan kinerja promosi TTI yang diselenggarakan baik oleh Kemlu maupun K/L terkait. Kementerian Luar Negeri juga telah membentuk Kelompok Kerja (Pokja) Penguatan Diplomasi Ekonomi (SK Menteri Luar Negeri Nomor 111/B/KP/1/2015/01 Tahun 2015) untuk memperkuat koordinasi, komunikasi dan sinergi baik di lingkungan internal Kementerian Luar Negeri maupun dengan berbagai pemangku kepentingan seperti Kementerian/Lembaga dan kalangan usaha. Secara khusus, Pokja ditugaskan untuk mendukung pelaksanaan tugas Kementerian Luar Negeri dan Perwakilan RI dalam menunjang pencapaian target-target ekonomi dan kerja

${ }^{17}$ Sulthon Sjahril Sabaruddin, "Grand Design Diplomasi Ekonomi Indonesia: Sebuah Pendekatan Indeks Diplomasi Ekonomi," dalamJurnal Ilmiah Hubungan Internasional, Vol. 12, No. 1. Bandung: Universitas Katolik Parahyangan, 2016, h. 2

${ }^{18}$ Kementerian Luar Negeri Republik Indonesia, “Diplomasi Indonesia 2010,” dalam www.kemlu.go.id 
sama pembangunan, menanggapi, mendorong dan memantau tindak lanjut peluang dan inquiry, memfasilitasi matchmaking, serta dokumentasi berbagai kesepakatan di bidang ekonomi maupun kerja sama pembangunan. ${ }^{19}$

Pada 2016 yang lalu, Kemenlu telah meluncurkan situs web Diplomasi Ekonomi. Situs web Diplomasi Ekonomi merupakan salah satu upaya Pokja untuk mendukung kinerja Kemlu dalam hal promosi, penyebaran informasi, dan pelayanan online terkait diplomasi ekonomi. Dengan adanya situs ini, para pengusaha lokal maupun investor asing dapat mengetahui peluang-peluang strategis dalam hal perdagangan, investasi, pariwisata, maupun kerja sama pembangunan di Indonesia dan luar negeri. Dengan laman ini, kita bekerja keras untuk menjalankan diplomasi ekonomi Indonesia. ${ }^{20}$

Cara lain yang dilakukan Indonesia adalah menyelesaikan perundingan Free Trade Agreement (FTA) maupun Preferential Trade Agreement (PTA) dengan mitra-mitra strategis secara terbatas, yaitu dalam konteks regional dengan Regional Comprehensive Economic Partnership (RCEP) dan ASEAN-Hong Kong FTA, maupun konteks bilateral dengan Uni Eropa, European Free Trade Association (EFTA), Australia, Chile, dan Jepang. ${ }^{21}$

Sesuai arahan Presiden RI untuk memprioritaskan pasar potensial, sejak awal tahun 2017 Pemerintah mulai mendorong percepatan penyelesaian perundingan FTA/PTA dengan penetapan target penyelesaian tahun 2017-2018, serta penambahan pasar-pasar potensial termasuk mitra-mitra non-tradisional.Kementerian Luar Negeri RI juga menyampaikan agar seluruh Perwakilan dapat menjajaki kerjasama ekonomi/ perdagangan dengan negara akreditasi dalam bentuk. ${ }^{22}$

Berikut ini beberapa perjanjian kerjasama ekonomi tersebut:

Preferential Trade Agreement (PTA)

Pembentukan PTA didasarkan pada Artikel XXIV General Agreement on Tariffs and Trade (GATT) 1994 dan Enabling Clause tahun 1979 sebagai preferensi

${ }^{19}$ Chariri Makmun, "Prioritas Politik Luar Negeri di Bidang Diplomasi Ekonomi," dalamTabloid Diplomasi, versi PDF, edisi 6 November 2017.

20 "Kemlu Luncurkan Situs Web Diplomasi Ekonomi”, dalam http://www. tabloiddiplomasi.org, diakses 3 April 2018

${ }^{21}$ Randy Aulia Isan, "Kepentingan Republik Rakyat Tiongkok dalam Pembentukan Regional Comprehensive Economic Partnership (RCEP), " dalam JOM FISIP, Vol. 4, No. 1-Februari, 2017, h. 2

${ }^{22}$ www.kemlu.go.id 
Millatī, Journal of Islamic Studies and Humanities, Vol. 3, No. 1, Juni 2018: 73-101

perdagangan yang diberikan secara unilateral. Dalam perkembangannya, PTA saat ini lebih mengarah ke perjanjian penurunan tarif perdagangan barang (dan tidak harus secara unilateral). Cakupan dan derajat PTA lebih kecil dibandingkan FTA serta customized pada produk-produk tertentu.

Free Trade Agreement (FTA)

FTA didasarkan pada ketentuan WTO khususnya Artikel XXIV dan GATT 1994 dan Artikel 5 General Agreement on Trade in Services (GATS) 1994. FTA mencakup isu-isu yang lebih luas dari sekedar isu perdagangan barang, tetapi juga termasuk isu-isu non-perdagangan barang seperti perdagangan jasa dan investasi. FTA pada dasarnya adalah kesepakatan blok perdagangan yang dibentuk untuk secara umum mengurangi hambatan tarif dan non-tarif dan meningkatkan perdagangan barang maupun jasa antar sesama anggotanya.

Comprehensive Economic Partnership Agreement (CEPA)

Salah satu tren FTA yang tengah berkembang adalah perjanjian dalam bentuk CEPA, yang memiliki cakupan lebih luas dan komprehensif, yang antara lain, meliputi lingkungan hidup dan pembangunan berkelanjutan, tenaga kerja, pengadaan barang/jasa pemerintah, e-commerce, peningkatan kapasitas, dan lain-lain.

Setelah tiga tahun Pemerintahan Jokowi-Jusuf Kalla berjalan sejak 2014, banyak pengamat yang menilai bahwa kebijakan luar negeri Joko Widodo mengalami peningkatan positif. Dalam beberapa pertemuan baik bilateral maupun multilateral, kemampuan diplomasi Indonesia mendapatkan pengakuan. ${ }^{23}$ Jokowi mengatakan bahwa melalui perdagangan itu Indonesia bukan hanya menyinggung sektor perdagangan semata. Melainkan menembus batas diplomasi ekonomi Indonesia di dunia. Begitu pula saat PT INKA berhasil mengekspor 150 gerbong kereta api ke Bangladesh dan saat produk Indonesia masuk ke pasar-pasar nontradisional di Afrika, Timur Tengah dan Asia. ${ }^{24}$

\section{Posisi Politik Indonesia Menjelang Arab Spring}

Dengan mengutip Wineburg (2001), Jannet dan Carla mengatakan bahwa the past is strange and familiar at the same time. Sebagai jalan keluarnya, Jannet dan Carla menguti Khun (1994), in order to interpret historical events, one has to apply a

\footnotetext{
${ }^{23}$ www.mediaindonesia.com

${ }^{24}$ www.kompas.com
} 
wide range of general knowledge of how social variables function and interrelate these in order to interpret the specific events under consideration. ${ }^{25}$ Sejarah masa lalu itu jelas sekaligus gelap. Dalam artian, sekalipun posisi dan peran sudah jelas, tetapi sangat terbuka untuk diragukan dan dipertanyakan ulang.

Butuh kontekstualisasi atas posisi diplomatik politik Indonesia di kawasan Timur Tengah. Oleh karenanya, penting memulai pembicaraan ini dengan berangkat dari laporan tahunan Kementerian Luar Negeri Republik Indonesia tentang Diplomasi Indonesia tahun 2010 semasih rezim di bawah administrasi Susilo Bambang Yudhoyono. Laporan ini berbicara hasil yang sudah dicapai oleh Indonesia selama melakukan kerjasama di bidang politik dengan negara-negara Timur Tengah yang terdiri dari: Aljazair, Arab Saudi, Bahrain, Irak, Kuwait, Lebanon, Libya, Maroko, Mesir, Oman, Palestina, Uni Emirat Arab, Qatar, Sudan, Suriah, Tunisia, Yaman dan Yordania. Pencapaian ini juga menggambarkan nalar diplomatik-politis Negara Kesatuan Republik Indonesia. Di samping laporan pencapaian ini adalah bahan dasar utama untuk mengoperasikan framework historical reasoning ala Jannet dan Carla.

Hubungan diplomatik bilateral Indonesia-Aljazair, misalnya, sampai tahun 2010 berjalan tanpa kendala sejak pertama kali di Konferensi Asia Afrika tahun 1955 di Bandung, dimana Indonesia mendukung penuh kemerdekaan Aljazair. ${ }^{26}$ Normalnya hubungan baik di bidang politik ini berdampak nyata pada peningkatan perdagangan Indonesia-Aljazair sebesar 5\%.

Berbeda halnya hubungan bilateral Indonesia-Arab Saudi. Kualitas diplomasi politik Indonesia-Arab Saudi tercermin pada perhatian pemerintah dari kedua negara yang semakin besar terhadap Tenaga Kerja Indonesia (TKI). Urusan Warga Negara Indonesia (WNI) yang menjadi TKI di Arab Saudi menjadi kata kunci yang merekatkan dua negara. Pemerintah RI berterimakasih pada Pemerintah Saudi yang memberikan kesempatan kerja kepada TKI Informal maupun TKI Ekspatriat, sekalipun di tahun 2010 belum ada Memorandum of Understanding (MoU) Ketenagakerjaan. ${ }^{27}$

Tahun 2010, KBRI di Bahrain baru dibuka tanggal 29 Desember, karena sebelumnya dirangkap oleh KBRI Kuwait. Dengan begitu, ada indikasi Bahrain-

${ }^{25}$ Jannet van Drie dan Carla van Boxtel, "Historical Reasoning: Towards a Framework for Analyzing Students' Reasoning about the Past,” ibid., h. 95

${ }^{26}$ Kementerian Luar Negeri Republik Indonesia, Diplomasi Indonesia 2010, (Jakarta: Gramedia, 2010), h. 66

${ }^{27}$ Ibid., h. 67 
Millatī, Journal of Islamic Studies and Humanities, Vol. 3, No. 1, Juni 2018: 73-101

Indonesia telah memasuki era kehangatan hubungan diplomatik. Di tanggal 29 Desember 2010 ini, juga ada peresmian perwakilan Indonesia di Muscat, Oman, yang sebelumnya dirangkap oleh perwakilan di Riyadh. ${ }^{28}$

Sedangkan dengan Kuwait sendiri, tahun 2010, Indonesia mulai menyusun Perjanjian Promosi Penanaman Modal (P4M). Selain itu, 5-6 Desember 2010, RI-Kuwait menyepakati untuk merevisi Air Transport Agreement yang ditandatangani kedua negara tahun 1993. Penandatanganan perjanjian penempatan TKI di Sektor Formal dan Domestik juga dilakukan untuk merevisi perjanjian tahun 1996. Dengan kata lain, diplomasi politik RI-Kuwait terus membaik dan memperbaiki diri terus-menerus. ${ }^{29}$

Sedangkan hubungan diplomatik RI-Lebanon jauh lebih baik lagi. Indonesia mengirim pasukan perdamaian yang tergabung dalam Kontingen Garuda XXIII-D ke wilayah Lebanon Selatan. Tahun 2007, Indonesia juga mengirim Kontingen Garuda XXIII-A. Tahun 2009 mengirim Satgas Maritim UNIFIL KRI Diponegoro dan dilanjut tahun 2010 dengan mengirim KRI Frans Kaisiepo. Kerjasama di bidang politik dan militer ini memang masuk akal karena mempertimbangkan kebutuhan Lebanon saat itu. ${ }^{30}$

Pola yang berbeda tapi hampir senada terjadi bersama Libya. IndonesiaLibya saling dukung-mendukung dalam mengusulkan beberapa usulan dan pencalonan di level internasional, misal terkait perdamaian Palestina, masalah nuklir bertujuan damai, baik di tingkat PBB maupun Organisasi Kerjasama Islam (OKI). ${ }^{31}$

Dengan Mesir, Indonesia sudah memiliki sejarah panjang bahkan sejak pra kemerdekaan. Sehingga di tahun 2010, pemimpin kedua negara hanya tinggal memikirkan bagaimana peningkatan kemesraan mereka. Di sela-sela SMU PBB ke-65, tanggal 28 September 2010, Menteri Luar Negeri Mesir Ahmed Aboul Gheit mengundang Menteri Luar Negeri Indonesia Hassan Wirajuda untuk berbincang soal peningkatan hubungan bilateral kedua negara. ${ }^{32}$

Tanggal 28-29 Mei 2010, Presiden Palestina Mahmoud Abbas berkunjung ke Indonesia. Ini kunjungan kedua kalinya setelah tahun 2007. Dalam kesempatan ini, Indonesia mendukung kemerdekaan Palestina, berjanji

\footnotetext{
${ }^{28}$ Ibid., h. 68 dan 71

${ }^{29}$ Ibid., h. 68

${ }^{30}$ Ibid., h. 69

${ }^{31}$ Ibid., h. 69

${ }^{32}$ Ibid., h. 70
} 
memberikan bantuan Rp. 20 miliar untuk pembangunan rumah sakit di Jalur Gaza, dan menyusun Capacity Building Programs untuk peningkatan kualitas SDM untuk menyambut kemerdekaan Palestina melalui skema kemitraan strategis intra-kawasan Asia-Pasifik. Pada BDF III tanggal 10 Desember 2010, Menlu Palestina meminta Menlu RI untuk meningkatkan peran aktif Indonesia dalam proses perdamaian Timur Tengah, dan permintaan tersebut disambut positif oleh utusan Indonesia. ${ }^{33}$

Kehangatan yang sama didapat oleh Republik Indonesia dari Uni Emirat Arab (UEA), yang mendorong integritas dalam negeri Indonesia dan mendukung berbagai pencalonan Indonesia di badan-badan regional maupun internasional. Kunjungan para pejabat dari kedua negara semakin inten. Tanggal 18-19 Oktober 2010, Menlu UEA Syeikh Abdullah bin Zayed Al Nahyan berkunjung ke Indonesia untuk menandatangani dua naskah: MoU Pemerintah Indonesia dan Pemerintah UEA mengenai Pembentukan Komisi Bersama untuk Kerjasama Bilateral, dan Persetujuan Pembebasan Visa bagi Pemegang Paspor Diplomatik, Dinas dan Khusus. ${ }^{34}$

Hubungan baik juga terjadi antara Qatar-Indonesia. Kedua negara berkomitmen untuk meningkatkan hubungan bilateral mereka. Tahun 2010 adalah tahun penjajakan untuk membuat MoU Pembentukan Sidang Komisi Bersama RI-Qatar. MoU ini akan menjadi landasan pelaksanaan SKB Perdana RI-Qatar. ${ }^{35}$

Sedangkan hubungan RI-Sudan tidak perlu dibicarakan lagi. Sebelum kedua negara belum merdeka, mereka sudah menjalin kerjasama, dilanjutkan lagi pada saat Sudan ikut serta KAA Bandung 1955. Sudan mendukung persatuan dan keutuhan NKRI dan mengutuk segala upaya yang mengancam persatuan. Sebaliknya, Indonesia memandang seluruh proses perdamaian menyeluruh yang tengah berlangsung di Sudan sudah sesuai dengan ketentuan internasional, oleh sebab itulah, perlu diberi dukungan oleh semua pihak baik di level domestik, regional, maupun internasional. ${ }^{36}$

Di sela-sela sesi ke-65 PBB tanggal 28 September 2010, Indonesia dan Sudan mengadangan pertemuan untuk membahas hubungan bilateral diplomatik mereka. Pada pertemuan itu dibahas isu Darfur dan Referendum Sudan Selatan.

\footnotetext{
${ }^{33}$ Ibid., h. 71

${ }^{34}$ Ibid., h. 71

35 Ibid., h. 72

${ }^{36}$ Ibid., h. 73
} 
Indonesia tetap konsisten dengan posisinya yang mendorong pencapaian solusi damai yang komprehensif. Sebagai ucapan terimakasih, Menlu Sudan atas nama negara dan rakyat Sudan memberikan apresiasi yang tinggi. Menlu Sudan sangat puas dengan kinerja Formed Police Unit Indonesia di United Nation African Mission in Darfur; suatu kinerja yang bisa diterima semua rakyat Sudan.

Hubungan diplomatik Indonesia-Suriah semakin meningkat. Hal itu tercermin dari peningkatan kerjasama yang semakin meluas ke ranah-ranah ekonomi. Pada Oktober 2010 telah ditandatangi kesepakatan kerjasama ekonomi Agreement on the Establishment of a Syrian-Indonesian Business Council. Berikutnya adalah hubungan Indonesia-Tunisia. Tahun 2010 adalah tahun ke-50 hubungan diplomati kedua negara yang sudah dimulai tahun 1960. Berbagai kegiatan seremonial dibuat demi memeriahkan hubungan yang semakin harmonis itu. Salah satunya tanggal 12-15 Juni 2010, Indonesia mengirim KRI Dewaruci dimana seluruh diplomat, para pejabat dan masyarakat diundang untuk mengunjungi KRI Dewaruci. ${ }^{37}$

Selanjutnya hubungan Indonesia-Yaman maupun Indonesia-Yordania. Tidak ada yang problematis di antara mereka. Sebaliknya, terus menunjukkan trend positif dan naik. Hal itu tercermin dari peningkatan hubungan ekonomi. Di tahun 2010 misalnya, perdagangan RI-Yaman meningkat sebesar 28.51\%. Dimana-mana apabila indeks ekonomi meningkat, hubungan politik mendekati sempurna. ${ }^{38}$

\section{Perang Narasi dalam Menggambarkan Indonesia}

Namun, posisi dan peran diplomatik Indonesia di Timur Tengah seperti yang diurai di atas masih terbuka diartikan dengan cara berbeda. Demikianlah karakter sejarah masa lalu, strange and familiar at the same time. Jannet dan Carla mengutip Barton and Levstik (2004) juga Spoehr and Spoehr (1994) dengan mengatakan: because historical accounts are based upon various kinds of sources that often contain partial and contradictory information and because historical interpretations are not definite, assertions and claims about the past must be supported by rational arguments, which, in turn, should be based upon well-evaluated evidence. Historical reasoning does not mean just giving an opinion or a viewpoint; it is the arguments and evidence used to support the opinion that counts. ${ }^{39}$

\footnotetext{
${ }^{37}$ Ibid., h. 74

${ }^{38}$ Ibid., h. 75

${ }^{39}$ Jannet van Drie dan Carla van Boxtel, "Historical Reasoning: Towards a Framework for Analyzing Students' Reasoning about the Past,” ibid., h. 97
} 
Kekhawatiran Jannet-Carla sangat beralasan, termasuk bagaimana citra Indonesia dibangun oleh peneliti asing seperti Büllet Aras dan Sinan Ekim. Dalam penelitiannya, Büllet Aras dan Sinan Ekim berusaha kuat untuk mengukur sejauh mana jangkauan diplomasi politik Indonesia yang bersifat "Bebas-Aktif" itu di kawasan Timur Tengah, serta hasil-hasil macam apa yang dicapai. ${ }^{40}$ Di level ini, Aras dan Ekim memang berhasil menggambar akar historis prinsip politk bebas-aktif dari Indonesia dengan merujuk pada pidato Bung Hatta dan dalam hal menggambarkan praktek prinsip bebas-aktif tersebut dalam realitas politik, seperti bekerjasama dengan Amerika di tahun 1952, Rusia 1954, Asia-Afrika 1955, China 1990, Gerakan Non-Blok 1992-1995, dan Asia-Pasific Economic Cooperation (APEC) 1994.

Selain itu, Bullet Aras dan Sinan Ekim menggambarkan pemerintahan SBY sebagai ASEAN (Association of Southeast Asian Nations), Asia-Pacific Economic Cooperation (APEC), Southwest Pacific Dialogue (SwPD), Asian Cooperation dialogue (ACD), membentuk Asian Defense Ministers Meeting (ADMM), terlibat dalam East Asia Summit (EAS), menguapakan penyelesaian konflik perbatasan Thailand-Cambodia, konflik Laut China Selatan, bahkan memotori Bali DemocracyForum.

Namun, dengan mengutip tulisan Teddi Kurniawan (2013), Bullet Aras dan Sinan Ekim menjadi gagal saat menilai dan menggambarkan pemerintahan SBY maupun Jokowi. Gagal dalam ukuran tidak sejalan dengan prestasi laporan tahunan resmi Pemri. SBY dinilai absen dalam konflik di Mesir antara Mursi dan militer; SBY dan Indonesia dinilai tidak memberikan bantuan pada penggulingan Mubarak tahun 2011; dan Indonesia tidak mau mengajarkan para pemberontak mewujudkan tujuan mereka. Penilaian miring terhadap Indonesia di bawah rezim SBY terjadi dengan menghadirkan kasus krisis di Suriah. Menurut Aras dan Ekim, SBY mengatakan agar Bashar Al Assad mengundurkan diri dan membiarkan rakyat memiliki pemimpin pilihan mereka. Seruan ini tanpa diikuti dengan aksi nyata yang lebih konkrit.

Dalam penilaian Aras dan Ekim, Indonesia-SBY memilih abstain dalam sebuah voting terkait Resolusi UNGA Mei 2013 yang mengutuk rezim Bashar al Assad dan menolak mengakui National Coalition for Syrian Revolutionary dan kekuatan-kekuatan oposisi sebagai teman. Sekalipun Indonesia menandatangani Resolusi UNGA 2012, tapi sebatas menyerukan perdamaian dan mendorong

${ }^{40}$ Büllet Aras dan Sinan Ekim, "Indonesia and Arab Spring," ibid., h. 2 
Millatī, Journal of Islamic Studies and Humanities, Vol. 3, No. 1, Juni 2018: 73-101

stabilitas negara, bukan pengiriman kekuatan militer. ${ }^{41}$

Setelah mengutip peristiwa-peristiwa dalam sejarah dan fakta-fakta yang bisa ditemukan, Bullet Aras an Sinan Ekim membangun argumentasinya sendiri. Bagi mereka, ketidakmauan (unwillingness) Indonesia terlibat jauh dalam upaya perdamaian dan penyelesaian konflik di Timur Tengah dari sudut pandang keuntungan ekonomi. Terlibat dalam ekstrimitas posisi akan merugikan Indonesia, sebab Indonesia tidak punya kepentingan langsung dari mendorong revolusi di Suriah, Indonesia juga tidak akan terkena dampak langsung dari Perang Sipil di Libya, Kairo dan Tunisia. ${ }^{42}$

Penilaian yang sama menimpa atas presiden Joko Widodo. Setelah memetakan posisi Jokowi sebagai presiden yang tidak punya bekal pengetahuan dan jaringan militer dibanding presiden SBY; sebagai presiden yang lebih memusatkan pada kepentingan domestik daripada internasional; Aras dan Ekim mengatakan bahwa Timur Tengah tidak masuk dalam agenda besar Jokowi. ${ }^{43}$ Dari pernyataan ini, mereka ingin mengesankan dengan tersirat bahwa Indonesia di era Jokowi semakin mundur dalam berkontribusi kepada problem dan konflik kawasan Timur Tengah.

Argumentasi yang Aras dan Ekim bangun untuk semakin memperkuat narasi mereka tentang melemahnya peran Indonesia di Timur Tengah pada era Jokowi adalah tentang respon Indonesia terhadap Islamic State of Iraq and Syria (ISIS) maupun fundamentalisme agama. Aras dan Ekim coba menyajikan bukti komitmen Indonesia era Jokowi untuk melawan ISIS dan fundamentalisme dengan menghadirkan sikap Jenderal TNI Moeldoko yang mengecam ISIS, kerjasama Indonesia dengan Amerika dan penandatanganan Kesepakatan Kerjasama Pertahanan dengan Arab Saudi Januari tahun 2014. Tetapi, hal itu dianggap tidak terlalu serius karena ada bukti bahwa Juli 2014 ada sebuah video yang menayangkan seruan untuk bergabung dengan gerakah khilafah dalam bahasa Indonesia, didukung data sekitar 2000 orang berkebangsaan Indonesia memakai paspor Amerika untuk bergabung dengan ISIS. Diperkirakan bahwa di Indonesia ada jejaring cells teroris yang mendukung ISIS. ${ }^{44}$

Kisah tentang Abu Wardah Santoso, orang Indonesia pertama yang berbaiat pada ISI dan bergerak di pegunungan di daerah Sulawesi, membuat

\footnotetext{
${ }^{41}$ Ibid., h. 3

${ }^{42}$ Ibid., h. 4

${ }^{43}$ Ibid., h. 4

${ }^{44}$ Ibid., h. 5
} 
citra negatif tentang komitmen Indonesia pada perdamaian dunia, khususnya Timur Tengah, semakin korosi. Sekaipun 19 September 2013, gabungan TNI Polri berhasil menemukan markas persembunyian Abu Wardah Santoso di daerah Pesisir Poso, tapi aktifitas Santoso masih dicurigai oleh orang asing. Jaringan cells semacam ini sedang menggalang dana untuk mendukung teroris di Timur Tengah, Suriah khususnya.

Lebih parah lagi, pencitraan negatif Indonesia oleh orang asing dilakukan dengan cara menghubungkan keterlibatan generasi muda Indonesia dalam gerakan ISIS dengan gerakan Anti-Kristen yang berlangsung baik di era SBY maupun Jokowi. Aras dan Ekim mengutip laporan kekerasan atas nama agama sebanyak 260 kasus di tahun 2010 dan 184 kasus di tahun 2011. Laporan dari Setara Institute juga dikutip yang menerangkan 230 kekerasan tahun 2013, 107 kasus di 2014. Semua kekerasan ini menargetkan kelompok minoritas, seperti Kristen, Ahmadiyah, Shiah dan kelompok aliran kepercayaan.Dengan nada yang pesimis, Arkas dan Ekim menyimpulkan dengan tegas: despite these successes in combatting fundamentalism, they are far from curbing either the threat of terrorismor religiously-inspired violence....As discussed, Jokowi is likely to throw Indonesia'sweight behind international efforts to battleagainst ISIS. ${ }^{45}$

Namun, riset Aaron L. Connely patut dibicarakan sebagai sebuah tawaran lain sekaligus wacana perbandingan.Komparasi (compare) adalah elemen penting dalam historical reasoning. Dalam kacamata Connely, Indonesia era SBY sangat luar biasa, karena bisa menjalin hubungan dengan China dan Amerika, sekaligus dengan Iran dan Korea Utara. Dimana nama-nama negara besar ini adalah poros-poros konflik. ${ }^{46}$ Connely dengan mengambil salah satu penasehat politik diplomatik Jokowo sebagai contoh, Luhut Binsar Panjaitan, menjelaskan bahwa Indonesia adalah partner negara-negara tetangga seperti Australia, Singapura, dan Malaysia untuk membicarakan pertahanan dalam negeri melawan para teroris jihadis yang kembali dari negara-negara Timur Tengah. ${ }^{47}$

Hal yang luput dari pembacaan Bullet Aras dan Sanin Ekim adalah profile Wakil Presiden, Jusuf Kalla-yang dalam kacamata penilaian A.L. Conneleysebagai peace-makers. Jusuf Kalla adalah wakil presiden baik di era SBY maupun Jokowi, dan dia aktif menjalankan diplomasi politik dalam maupun luar negeri yang bertujuan menciptakan perdamaian. Terbukti, Jusuf Kalla berhasil

${ }^{45}$ Ibid., h. 5

${ }^{46}$ Aaron L. Connely, Indonesian Foreign Policy Under President Jokowi, ibid., h. 2

${ }^{47}$ Ibid., h. 9 
mengajak damai konflik di Aceh, Thailand Selatan, Pilipina, dan Rakhine Myanmar-dimana umat muslim yang mayoritas menderita penindasan dan kekerasan oleh minoritas. Peristiwa besar lainnya adalah keterlibatan Indonesia dalam perdamaian konflik di Laut China Selatan, dimana negara-negara yang berkonflik dan saling klaim terdiri dari China, Taiwan, Vietnam, Pilipina, Brunai dan Malaysia. Di tingkat regional ini, kepemimpinan Indonesia diakui oleh Connely sebagai sikap politik yang patut diacungi jempol. ${ }^{48}$

Tidak saja kasus-kasus konflik di tingkat regional, hal yang secara langsung menyangkut konflik kontroversial di Timur Tengah juga tidak lepas dari perbincangan elite politik Indonesia. Jika Bullet Aras dan Sanin Ekim melihat peran Indonesia dalam penyelesaian konflik Timur Tengah terlalu lembut, bahkan sering abstain, maka A.L. Connely memberikan jawaban yang luas. Sekalipun SBY lahir dari kalangan militer tetapi dia memilih jargon sejuta teman tanpa satupun musuh, sehingga hal-hal sensitif harus disikapi dengan lebih halus dan bijaksana. Sementara Jokowi yang tidak punya pengalaman militeristik dan kebijakan luar negeri sebagaimana SBY mustahil agresif apalagi melampaui agresifitas SBY.

Karenanya, tidak salah bila Jokowi lebih sering mengindari penolakan dari suara mayoritas elite politk dalam negeri. Apa yang diinginkan dalam riset Bullet Aras dan Sanin Ekim bukan tidak dilakukan oleh partai-partai oposisi di era SBY, misalnya dalam kasus sanksi Amerika atas proyek nuklir Iran. Hal yang sama dilakukan oleh partai-partai koalisi pendukung Prabowo untuk menekan Jokowi yang dinilai lemah dalam menentukan kebijakan yang bersifat mendamaikan..$^{49}$ Gambaran yang diungkap secara gamblang dalam riset Connely ini menimbulkan kecurigaan akan objektifitas riset Aras dan Eskim, karena seruannya serupa dengan seruan partai-partai politik dari kubu oposisi, baik era Jokowi maupun era SBY.

\section{Memilih "Suara dari Dalam": Versi Pemerintah}

Dari kasus narasi-narasi yang bersliweran seperti ini, persoalan meta konsep menjadi penting. Jannet dan Carla dengan mengutipLimón (2002) menjelaskan bahwa: meta-concepts are related to the methods used by historians to investigate and describe historical processes and periods. Limon mentions evidence, cause, explanation,

\footnotetext{
${ }^{48}$ Ibid., h. 10

${ }^{49}$ Ibid., h. 13
} 
empathy, time, space, change, source, fact, description, and narration... meta-concepts form the basis of historical knowledge and mediate students' understanding of substantive concepts. ${ }^{50}$

Meta konsep adalah metode yang digunakan oleh sejarawan dalam menginvestigasi dan menggambarkan proses maupun periode sejarah. Meta konsep bicara soal bukti, fakto penyebab, penjelasan, empati, waktu, ruang, perubahan, sumber, fakta, penjelasan dan narasi.Meta konsep membentuk basis pengetahuan historis dan memediasi pembaca sejarah memahami konsup substantif. Karena itulah, pertarungan narasi dan perebutan dominasi wacana yang dikemukakan baik oleh Bullet Aras dan Sanin Ekim maupun oleh Aaron L. Connely harus kembali diuji dengan menghadirkan bukti-bukti lain, yang lebih kuat. Salah satunya adalah data yang bersumber dari laporan resmi pemerintah Republik Indonesia, terkait kebijakan diplomasi politik luar negeri.

Salah satunya dapat kita komparasikan dengan pencapaian Pemri di tahun 2010 yang merupakan bagian dari era pemerintahan presiden Susilo Bambang Yudhoyono. Berdasarkan laporan tahunan Kementerian Luar Negeri Republik Indonesia tahun 2010, seperti yang dibahas di bagian awal, dapat kita temukan bahan perbandingan yang cukup memadai, dan melihat wajah Indonesia yang lebih positif..$^{51}$ Pencapaian Pemri tahun 2010 dapat diperkuat dengan laporan-laporan tahun berikutnya, misalnya tahun 2011.52

Untuk mendapatkan versi Pemerintah Indonesia, berikut akan dikutip secara kalimat per kalimat dengan tujuan meminimalisir misinterpretasi:

"Di tahun 2011, Indonesia-Arab Saudi menjalin hubungan diplomatik yang baik. Mereka bekerjasama dalam isu-isu terkait perdamaian Timur Tengah, khususnya melalui forum Organisasi Kerjasama Islam (OKI). Kendalanya hanya persoalan kasus hukum dimana WNI di Arab Saudi yang dieksekusi mati atas kasus pembunuhan. Dalam rangka memberi perlindungan WNI/ TKI di Arab Saudi maka kedua negara mengambil beberapa langkah-langkah, diantaranya: a) Mulai tanggal 1 Agustus 2011 Pemerintah Indonesia menerapkan kebijakan moratorium penempatan TKI informal ke Arab Saudi; dan b) Untuk

${ }^{50}$ Jannet van Drie dan Carla van Boxtel, "Historical Reasoning: Towards a Framework for Analyzing Students' Reasoning about the Past,” ibid., h. 101

${ }^{51}$ Direktorat Informasi dan Media Kementerian Luar Negeri Republik Indonesia, Diplomasi Indonesia 2013, Cet. I, (Jakarta: Direktorat Informasi dan Media Kemlu RI, 2014), h. $111-130$

${ }^{52}$ Kementerian Luar Negeri RI, Buku Diplomasi Indonesia Tahun 2011, (Jakarta: Kemlu, 2011), h. 94-110 
Millatī, Journal of Islamic Studies and Humanities, Vol. 3, No. 1, Juni 2018: 73-101

menangani penyelesaian beberapa kasus hukuman mati WNI di Arab Saudi, Kemlu mengirimkan Satgas Perlindungan WNI ke Arab Saudi sejak awal Agustus 2011." 53

Dengan begitu, tidak benar bahwa Indonesia dicitrakan sebagai negara yang kurang aktif dalam menyongsong perdamaian dunia umumnya dan Timur Tengah khususnya. Tentu saja, jalur yang tempuh Indonesia lebih bijaksana dan lembut, soft. Karena itulah, Indonesia terus membangun relasi dengan negara-negara Timur Tengah. Jika belum ada KBRI maka dibuatlah KBRI di sana. Misalnya, tahun 2011 juga menjadi penanda penting hubungan IndonesiaBahrain, yang ditandai dengan keikutsertaaan pejabat Bahrain di KTM NonBlok Balik Mei 2011. Relasi Indonesia-Baghdad juga membaik, ditandai dengan diaktifkannya kembali KBRI Baghdad. Di sela-sela pelaksanaan KTM Ke-16 GNB di Bali,Menlu RI telah mengadakan pertemuan denganMenlu Irak, Hoshyar Zebari pada tanggal 26 Mei2011. ${ }^{54}$

Tuduhan lain bahwa Indonesia tidak mengirim pasukan perdamaian juga tidak benar. Berikut versi langsung dari pemerintah RI:

"Di tahun yang sama, di sela-sela pelaksanaan KTM Ke-16 GNB di Bali, Menlu RI telah mengadakan pertemuan dengan Menlu Kuwait, Dr. Mohammad Sabah Al Salem Al Sabah pada tanggal 25 Mei 2011. Dalam pertemuan tersebut, Menlu antara lain menyampaikan bahwa Indonesia terus mengikuti peran konstruktif Kuwait dalam Gulf Countries Cooperation (GCC) khususnya terkait dengan perkembangan yang sangat dinamis di Timur Tengah dalam mempromosikan perdamaian di kawasan tersebut. Bahkan, berdasar hubungan IndonesiaLebanon, kita lihat kontribusi pasukan Indonesia (Kontingen Garuda) dalam UNIFIL. Jumlah keseluruhan personel kontingen Garuda (KONGA)/UNIFIL di Lebanon hingga November 2011 adalah 1450 personel. Jumlah tersebut telah menempatkan Indonesia sebagai negara penyumbang terbesar pasukan di United Nations Interim Force in Lebanon (UNIFIL)." 55

Bukan saja di Lebanon, terkait konflik horizontal di Libya, sikap Indonesia senada dengan DK PBB. Berikut pernyataan Pemri:

"DK PBB mensahkan resolusi 1970/2011 pada 26 Februari 2011 yang meminta Pemerintah Libya untuk melindungi warga sipil dan warga negara asing; memberlakukan embargo senjata dan travel ban serta membekukan aset

\footnotetext{
${ }^{53}$ Ibid., h. 95-96

${ }^{54}$ Ibid., h. 96

${ }^{55}$ Ibid., h. 97
} 
keuangan dan ekonomi milik rezim Khadafi. Pada 1 Maret 2011, Liga Arab membekukan keanggotaan Libya disusul pembekuan keanggotaan Libya pada Dewan HAM PBB. Setelah itu, pada 17 Maret 2011, DK PBB mensahkan resolusi 1973/2011 tentang pemberlakuan no fly zone, ketentuan "to take any necessary measures", seruan untuk gencatan senjata dan pencarian solusi politik damai untuk Libya dengan tujuan utama untuk melindungi warga sipil dan daerah-daerah berpenduduk sipil.

Pada pada tanggal 21 Oktober 2011 sesuai instruksi Presiden RI, Menlu RI menyampaikan bahwa bangsa Indonesia menanti suatu titik dimana kekerasan dapat dihentikan, perdamaian dapat dimajukan dan rekonsilasi dapat dimulai. Pemerintah Indonesia mengharapkan agar berbagai kalangan di Libya dapat memulai tahapan baru dengan mengedepankan pendekatanpendekatan damai dalam mengatasi berbagai tantangan yang dihadapi ke depan dan dengan menghormati nilai-nilai yang menjadi kehendak dan pilihan rakyat Libya." ${ }^{56}$

Semakin tidak masuk akal tuduhan riset dari para peneliti asing yang mencitrakan keterlibatan Indonesia dalam proses perdamaian Timur Tengah sangat minim, apabila dilawan dan dibuktikan dengan pernyataan Pemri berikut ini:

Di tahun 2011 juga, hubungan Indonesia dengan Palestina ditandai dengan komitmen dan dukungan Indonesia yang semakin kuat bagi kemerdekaan Palestina baik di tingkat bilateral, regional maupun multilateral serta melalui upaya pengembangan kapasitas. Kontribusi utama diplomatik Indonesia bagi perjuangan Palestina adalah melalui penggalangan masyarakat internasional untuk mendukung pengakuan terhadap kemerdekaan Palestina. Pada Pertemuan Tingkat Menteri Gerakan Non-Blok (GNB) di Bali, pada tanggal 23 - 27 Mei 2011, negara-negara anggota GNB memperkuat komitmennya terhadap perjuangan rakyat Palestina dengan menyambut rekonsiliasi faksi-faksi Palestina sebagai langkah maju yang sangat diperlukan dalam penuntasan isu Palestina secara menyeluruh dan adil melalui pembahasan dan pengesahan Deklarasi mengenai Palestina dan Deklarasi mengenai Tahanan Politik Palestina. GNB mendukung gagasan Indonesia bagi suatu rencana aksi melalui NAM Ministerial Committee untuk penggalangan suara terhadap pengakuan Palestina sebagai anggota PBB. ${ }^{57}$

Secara umum, praktek diplomasi politik Indonesia di Timur Tengah terkait konflik dan perdamaian memang bijaksana, berbeda dengan karakter

\footnotetext{
${ }^{56}$ Ibid., h. 98

${ }^{57}$ Ibid., h. 101
} 
Millatī, Journal of Islamic Studies and Humanities, Vol. 3, No. 1, Juni 2018: 73-101

dan mentalitas budaya orang Timur Tengah sendiri, yang lebih mendahulukan kekerasan militer daripada kepala dingin. Karena itulah, apabila Bullet Aras dan Sanin Ekim tidak melihat komitmen Indonesia maka hal itu sudah berlebihan. Berikut versi Pemri tentang konflik Mesir yang juga diangkat oleh Bullet Aras dan Sanin Ekim:

Tanggal 25 Januari 2011, perkembangan politik dalam negeri Mesir sedang dalam proses menjadinegara demokrasi menyusul pecahnya revolusi. setelah pengunduran diri Presiden HosniMubarak pada 11 Februari 2011, Pemerintah RI langsung menyampaikan pernyataan sikap,menyambut baik perkembangan positif yang terjadi dengan harapan Mesir ke depan akan Iebih baikserta tetap konsisten mendukung peran regional Mesir.Menlu RI berkunjung ke Cairo pada 14 April 2011 guna menunjukkan solidaritassekaligus membahas upaya peningkatan kerja sama, baik pada tingkat bilateral maupun pada tataranmultilateral, termasuk pelaksanaan KTM ke-16 GNB di Bali, 25-27 Mei 2011 dan upaya menggalangdukungan bagi Palestina yang berjuang mencari pengakuan dan menjadi anggota PBB.

Pasca revolusi, hubungan RI-Mesir semakin diperkuat dengan komitmen RI untuk mendukungproses demokratisasi di Mesir yang diimplementasikan melalui kegiatan sharing of experience dan lessons learned. Untuk kegiatantersebut, sejumlah tokoh nasional seperti mantan Presiden BJ Habibie, mantan Ketua DPR Amien Rais,Letjen (Purn.) Agus Widjojo, dan Prof. Dr. Dewi Fortuna Anwar diundang ke Mesir. Selain itu, dalamkurun waktu Mei-Oktober, Institute for Peace and Democracy yang berkedudukan di Balimenyelenggarkan tiga kali Workshop on Egypt- Indonesia Dialogue on Democratic Transition diJakarta dan Cairo. ${ }^{58}$

Pendekatan lemah lembut, anti-kekerasan, dan menaati nalar humanis universal, Pemerintah Indonesia tunjukkan dalam menyikapi konflik Suriah. Hal itu tercermin dari laporan versi Pemri sendiri:

Terkait dengan perkembangan politik dan jatuhnya sejumlah korban sipil dalam gejolak olitik di Suriah,Pemerintah Indonesia telah menyatakan keprihatinannya atas perkembangan tersebut. Indonesia menegaskan bahwa penggunaan kekerasan dimanapun, termasuk di Suriah tidak akan pernah menyelesaikan masalah. Oleh karena itu, Indonesia memandang pentingnya penghentian konfrontasi yang menggunakan kekuatan militer. Indonesia meyakini bahwa satu-satunya solusi atas krisis di Suriah adalah melalui proses

${ }^{58}$ Ibid., h. 103 
politik yang inklusif, melanjutkan proses dialog dan melaksanakan reformasi yang memenuhi sematamata kepentingan rakyat Suriahsecara keseluruhan. ${ }^{59}$

Dari sini kita melihat bagaimana wacana dikontestasikan di ruang publik, berjalin kelindan dalam menarasikan peristiwa dan fakta sejarah. Pembaca sejarah yang tidak kritis akan terjebak oleh wacana dan narasi yang terkontruk sedemikian rupa, dan oleh karenanya, analisa teoritik historical reasoning ini membongkar bagaimana kesadaran, pemikiran, dan nalar dibentuk, konstruk, dilempar ke publik dalam wajah yang matang penuh argumentasi rasional, bukti ilmiah yang lengkap, serta koherensi dan keutuhan yang nyaris tidak menyisakan ruang tembak.

\section{Penutup}

Wajah diplomasi politik Indonesiadi kawasan Timur Tengah akan selamanya dihantui oleh keragaman perspektif sesuai temuan data dan sumber, serta bagaimana para peneliti mengajukan argumentasi masing-masing. Keragaman perspektif ini pada akhirnya mempunyai daya pikat sendiri, dan menjadi objek material dari kajian riset yang independen. Historical reasoning adalah teori dan pendekatan analisa untuk mengkaji gagasan sebagai fakta sejarah, dan oleh karenanya, teori dan pendekatan ini mengajak peneliti untuk sedikit melampaui peristiwa dan fakta sejarah yang selama ini dipahami.

Timur Tengah sebagai sebuah kawasan tentu memiliki banyak peneliti yang berkepentingan untuk berkontribusi di sana. Tetapi, tidak boleh dilupakan, bahwa negara-negara manapun juga punya pakar intelektual masing-masing yang kepentingannya pada Timur Tengah lebih kecil dibanding kepentingan bagi negaranya sendiri. Kepentingan yang berbeda, inheren dan melatarbelakangi para peneliti ini tidak lantas terhapus.Jejak-jejak bisa ditelusuri hingga ke dalam temuan riset mereka. Cara masing-masing memilih data, menyortir sumber, menyusun argumen dan membangun konsep adalah jejak kepentingan subjektif itu sendiri.

Dengan begitu, penggambaran tentang pencapaian diplomasi politik Indonesia dan Timur Tengah yang beragam dan bertolak belakang seperti dalam riset ini, dapat dihargai. Mencari objektifitas sudah tidak memungkinkan. Namun, apabila objektifitas dinilai sejauh mana lebih dekat pada versi dan perspektif pemerintah RI sendiri, maka sumber Pemri dapat lebih diandalkan.

${ }^{59}$ Ibid., h. 107 
Contohnya, Bullet Aras dan Sanin Ekim dari POMEAS memiliki visi dan misi yang jelas, yaitu demi perbaikan kualitas hidup masyarakat dan negara Timur Tengah. Karenanya, apapun yang coba dilakukan pemerintah Indonesia dinilai kurang maksimal, karenanya riset mereka tidak bersih dari bias interest. Begitupula Aaron L. Connely dengan Lowy Institute for International Policynya, memiliki kepentingan yang condong pada kebutuhan Australia sebagai negaranya. Sehingga, penilaian Connely tentang pencapaian diplomasi politik Indonesia dengan negara-negara Timur Tengah tidak perlu detail, secukupnya saja, sekedar memenuhi kebutuhan argumentasi.

Dalam teori analitik historical reasoning, cara setiap peneliti mengajukan argumen, data, menyusun narasi, wacana dan konsep menjadi objek material itu sendiri dalam kajian sejarah. Mengkaji nalar mereka sama saja dengan meneliti fakta sejarah sebagaimana yang dikenal oleh sejarawan klasik. Karenanya, historical reasoning memperlakukan nalar, kesadaran dan pemikiran yang muncul dari teks-teks penelitian sebagai objek netral yang bisu dan bisa dibicarakan kembali, sehingga peneliti tidak terjeban menjadikannya sebagai kebenaran melainkan "fakta" yang perlu disusun kembali.

Alhasil, bagi seorang pembaca sejarah, yang terpenting bukan kebenaran faktual sejarah, tetapi kepentingan apa yang dimilikinya dan kepada siapa akan berpihak. Penentuan perspektif semacam ini menolong dirinya saat berhadapan dengan sumber data, argumentasi, wacana yang saling rumit, bahkan bertolak belakang.

\section{Daftar Pustaka}

Aaron L. Connely, Indonesian Foreign Policy Under President Jokowi, (Australia: Lowy Institute, 2014).

Büllet Aras dan Sinan Ekim, "Indonesia and Arab Spring," dalam POMEAS POLICY PAPER, Istanbul, No. 6, Mei 2015.

Chariri Makmun, "Prioritas Politik Luar Negeri di Bidang Diplomasi Ekonomi," dalamTabloid Diplomasi, versi PDF, edisi 6 November 2017.

Jannet van Drie dan Carla van Boxtel, "Historical Reasoning: Towards a Framework for Analyzing Students' Reasoning about the Past," dalam Educ Psychol Rev, Springer, No. 20, Thn 2008.

Kementerian Luar Negeri RI, Buku Diplomasi Indonesia Tahun 2011, (Jakarta: Kemlu, 2011) 
Muhammad Tri Andika, "An Analysis of Indonesia Foreign Policy Under Jokowi's Pro-People Diplomacy," dalam Indonesian Perspective, Vol. 1, No. 2 (2016). R.P. Barston, Modern Diplomacy, (New York: Routledge, 2014).

Randy Aulia Isan, "Kepentingan Republik Rakyat Tiongkok dalam Pembentukan Regional Comprehensive Economic Partnership (RCEP), " dalam JOM FISIP, Vol. 4, No. 1-Februari, 2017.

Rizal Sukma, “'An Indonesian Vision,” dalam Abraham M. Denmark, Crafting A Strategic Vision: A New Era of USIndonesia Relations, (New York: Center for New American Security, 2010).

Sulthon Sjahril Sabaruddin, "Grand Design Diplomasi Ekonomi Indonesia: Sebuah Pendekatan Indeks Diplomasi Ekonomi," dalamJurnal Ilmiah Hubungan Internasional, Vol. 12, No. 1, Bandung: Universitas Katolik Parahyangan, 2016.

Triyono Wibowo, "Hubungan Strategis ASEAN-China, Pilar bagi Arsitektur Kerjasama Regional”, dalam Tabloid Diplomasi, No. 19, Tahun ke-II,. 15 Juni - 14 Juli, 2009.

www.kemlu.go.id

www.kemlu.go.id

www.kompas.com

www.mediaindonesia.com

www.tabloiddiplomasi.org 
